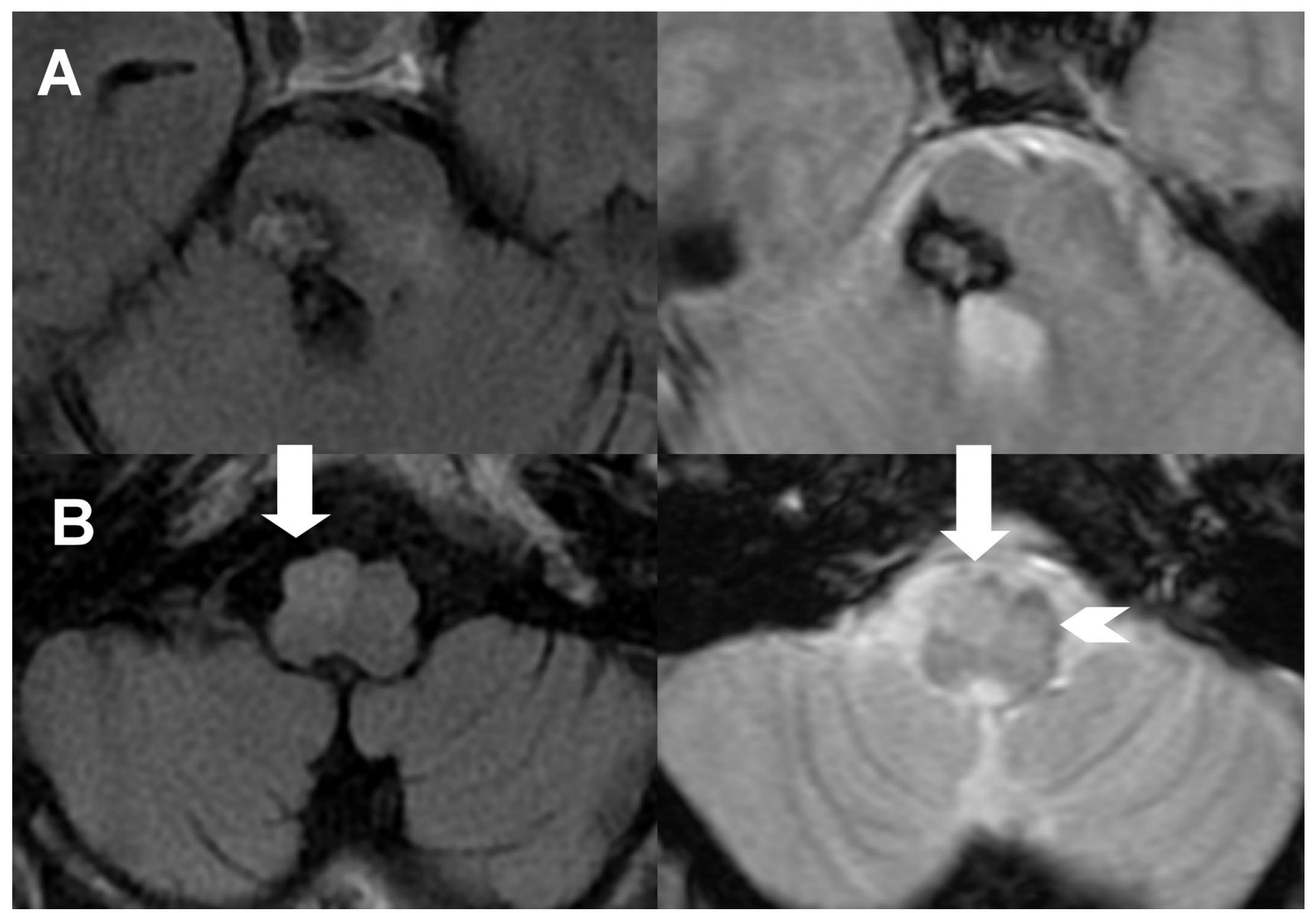

Figure. FLAIR (left column) and T2*-weighted gradient echo (right column) brain MRI showing a hemosiderin-laden cavernous malformation in the right tegmental region of the upper pons (A) and medulla (B). This lesion interrupts the central tegmental tract, the intra-brainstem component of the Guillain-Mollaret triangle, causing ipsilateral signal changes in, and enlargement of, the inferior olive (arrows). Note the normal appearing left inferior olivary nucleus (arrowhead).

\section{VIDE Cerebellar limb tremor and inferior olivary hypertrophy}

Alberto J. Espay, MD, MSc; and Fredy J. Revilla, MD, Cincinnati, $\mathrm{OH}$

A 49-year-old wheelchair-bound man was rendered left hemiparetic, dysarthric, and diplopic after a brainstem hemorrhage.

Additional material related to this article can be found on the Neurology Web site. Go to www.neurology.org and scroll down the Table of Contents for the October 10 issue to find the title link for this article.

Disclosure: The authors report no conflicts of interest.

Address correspondence and reprint requests to Dr. Alberto J. Espay, Assistant Professor of Neurology, Department of Neurology, University of Cincinnati, 231 Albert Sabin Way, MSB 4503, Cincinnati, OH 45267-0525; e-mail:alberto.espay@uc.edu
Several months later he developed a progressively disabling left arm tremor. Examination showed skew deviation, left hemipare-sis, left hemianesthesia, truncal ataxia, and a postural and action proximal left arm tremor (video). Brain MRI demonstrated a cavernous malformation in the right upper brainstem and enlarged ipsilateral inferior olivary nucleus secondary to a lesion in the central tegmental tract (figure). Cerebellar limb tremor is associated with contralateral hypertrophic inferior olive, analogous to secondary palatal tremor, ${ }^{1}$ whose delayed onset by weeks or months after injury may be due to compensatory changes in the motor system. ${ }^{2}$

1. Deuschl G, Toro C, Valls-Sole J, Zeffiro T, Zee DS, Hallett M. Symptom atic and essential palatal tremor. 1. Clinical, physiological and MRI analysis. Brain 1994;117:775-788.

2. Louis ED, Lynch T, Ford B, Greene P, Bressman SB, Fahn S. Delayedonset cerebellar syndrome. Arch Neurol 1996;53:450-454. 


\section{Neurology}

\section{Cerebellar limb tremor and inferior olivary hypertrophy \\ Alberto J. Espay and Fredy J. Revilla \\ Neurology 2006;67;1250 \\ DOI 10.1212/01.wnl.0000243947.26950.43}

\section{This information is current as of October 9, 2006}

\section{Updated Information \& Services}

Supplementary Material

References

Subspecialty Collections

Permissions \& Licensing

Reprints including high resolution figures, can be found at: http://n.neurology.org/content/67/7/1250.full

Supplementary material can be found at: http://n.neurology.org/content/suppl/2006/10/08/67.7.1250.DC1

This article cites 2 articles, 0 of which you can access for free at: http://n.neurology.org/content/67/7/1250.full\#ref-list-1

This article, along with others on similar topics, appears in the following collection(s):

\section{Cerebellum}

http://n.neurology.org/cgi/collection/cerebellum

\section{MRI}

http://n.neurology.org/cgi/collection/mri

Tremor

http://n.neurology.org/cgi/collection/tremor

Information about reproducing this article in parts (figures,tables) or in its entirety can be found online at:

http://www.neurology.org/about/about_the_journal\#permissions

Information about ordering reprints can be found online: http://n.neurology.org/subscribers/advertise

Neurology ${ }^{\circledR}$ is the official journal of the American Academy of Neurology. Published continuously since 1951, it is now a weekly with 48 issues per year. Copyright. All rights reserved. Print ISSN: 0028-3878. Online ISSN: 1526-632X.

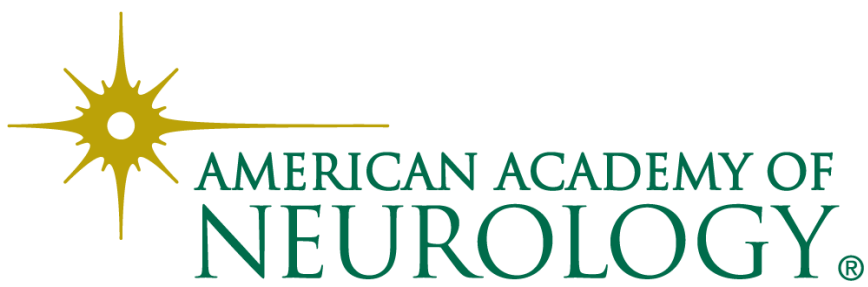

